\title{
Direito canônico e processo penal: colaboração processual na busca pela verdade
}

\section{Direito canônico e processo penal: colaboração processual na busca da verdade}

\section{Gabriel Bittencourt de Aguiar}

Advogado - OAB/SC - Dr. Honoris Causa em Direito Canônico pela Academia da Associação de Juízes do Tribunal Eclesiástico do Brasil - Rua Fúlvio Aducci no 656 - Bairro Estreito - Florianópolis/SC - Brasil

E-mail: gabrielaguiaradv@gmail.com

\section{Gilberto Callado de Oliveira}

Doutorado em Filosofia do Direito pela universidade de navarra, Espanha (1987), Professor contratado da Universidade Candido Mendes, Brasil - Ministério Público de Santa Catarina, Procuradoria-Geral de Justiça - Rua Bocaiúva no 1750 - Centro - CEP: 88015-904 - Florianópolis, SC - Brasil

E-mail: goliveira@mpsc.mp.br

\section{RESUMO}

Este artigo objetiva demonstrar a possibilidade real de colaboração processual entre o estado laico e os Tribunais Eclesiásticos. Como objetivos específicos tem-se mitigar alguns pontos desconhecidos, aproximando as possibilidades práticas e teóricas acerca de complementação e colaboração processual. Como resultados da pesquisa notou-se que mesmo diante de evidentes singularidades, é possível a colaboração entre as duas instituições, cujo livre convencimento para julgar suas lides com base nas provas licitamente obtidas na instrução processual, tanto na esfera processual penal quanto na esfera eclesial são regidas por um mesmo objetivo, visando o princípio da busca pela verdade real.

Palavras-chave: Direito Matrimonial Canônico, Tribunal Eclesiástico, Colaboração processual, Estado laico, Princípio da busca pela verdade real.

\section{ABSTRACT}

This article aims to demonstrate the real possibility of procedural collaboration between the secular state and the Ecclesiastical Courts. As specific objectives, some unknown points have been mitigated, approaching practical and theoretical possibilities about complementation and procedural collaboration. As a result of the research, it was noted that even in the face of obvious singularities, collaboration between the two institutions is possible, whose free conviction to judge their disputes based on the evidence lawfully obtained in the procedural instruction, both in the criminal procedural sphere and in the ecclesial sphere. governed by the same objective, aiming at the principle of the search for the real truth. 
Keywords: Canonical Matrimonial Law, Ecclesiastical Court, Procedural Collaboration, Secular State, Criminal Procedural Law, Principle of the Search for Real Truth.

\section{INTRODUÇÃO}

Com o objetivo de iniciar um aprofundamento acerca do direito matrimonial canônico e sua processualística, este artigo se propõe a demonstrar a possibilidade real de colaboração processual entre o estado laico e os Tribunais Eclesiásticos. O intuito deste estudo é seguir pioneiro visando a fusão processual de ambos, contudo, não pretende polemizar ou colocar à margem nenhum dos soberanos poderes, apenas expor suas limitações, constitucionais, burocráticas ou apenas de carência legal.

Diante de uma incontroversa dicotomia processual, este estudo objetiva mitigar alguns pontos desconhecidos, aproximando as possibilidades práticas e teóricas acerca de complementação e colaboração processual.

$$
\text { É necessário encarar o presente artigo como uma semente a ser }
$$
germinada, seu intuito é antever e comprovar a possibilidade do cumprimento de uma sentença canônica com o respaldo do estado laico, cujo objetivo final é provar que mesmo homologada Superior Tribunal de Justiça é possível o reconhecimento da singularidade do direito processual canônico promovendo sua fiel execução. De fato, a singularidade das formas processuais é o que chama atenção, contudo, vislumbra-se a possibilidade de empréstimo de provas tolhidas de um procedimento com o intuito de instrumentalizar ou complementar o outro.

O Código de Direito Canônico, foi promulgado em 25 de janeiro de 1983 e passou a vigorar a partir de novembro de 1983. Teve seu processo de revisão gestado ainda no pontificado do Santo Padre João XXIII, sua questão processual é definida no último livro (sétimo) do Código e vai dos cânones 1400 ao 1752 combinado com a Dignitas Connubii que são textos legislativos do Pontifício Conselho para instrução cujos Tribunais Diocesanos e Interdiocesanos devem observar ao tratarem de causas de nulidade de matrimônio. 
No Título VII - Capítulo II - De Probationibus in specie da Dignitas Connubii, é possível estudar o regramento processual no que se refere a declaração das partes, que dão causa à petição inicial chamada de Libelo, o artigo 178 da Dignitas Connubii expõe que:

Art. 178 - A parte legitimamente interrogada deve responder e expor toda a verdade. Se recusar a responder, compete ao juiz avaliar o que daí se pode deduzir para a prova dos fatos (cf. câns. 1531; 1534; 1548, § 2).

Tanto para o direito processual penal quanto para os Tribunais Eclesiásticos a estrutura do direito (como é conhecida) desempenha uma função fundamental em uma quantidade enorme de comunidades de nosso país, em especial as interioranas. A Igreja Católica geralmente teve a função de exercer fielmente a missão que avoca, que é a de promover e defender o vínculo, pautando sua missão na caridade, ordenamento, e hierarquias legais. A história comprova que a Igreja Católica possui uma representatividade de caráter internacional, pois é a única instituição confessional do mundo a ter um código de direito próprio reconhecido internacionalmente: O Código de Direito Canônico.

A Igreja Católica precisa de normas para que se torne visível sua estrutura pautada na hierarquia; para que seja reconhecida de forma organizada e focada no exercício das funções que lhe foram sagradamente confiadas, na administração dos sagrados sacramentos; para que se complementem, em conformidade a justiça (diferenciada da justiça laica) inspirada na caridade, nas relações mútuas entre os fiéis, definindo-se e garantindo os direitos de cada um; e, finalmente, para que as atividades dedicadas em prol de uma vida cristã mais perfeita sejam garantidas, protegidas e promovidas de acordo com as leis canônicas.

A estrutura do Direito como atualmente é conhecida, tem sua origem no direito canônico, contudo o estado laico e o direito eclesial possuem normas independentes e autônomas, próprias de suas ramificações. O Código de Direito Canônico entabula certos impedimentos que também estão dispostos em nossa 
esfera judicial, apesar das referidas leis não se comunicarem, ambas tratam de maneira singular e ao mesmo tempo congruente todos os processos que despendem sua atenção.

Afirmar que os Tribunais Eclesiásticos possuem legitimidade para reconhecer a validade de uma prova processual (pericial, documental ou testemunhal ) por meio de seus Notários não é uma falácia, pois a Igreja Católica possui autonomia para promover processos de nulidade matrimonial. Em contrapartida, é atingida pela falta de respaldo Estatal em garantir ao processo canônico, a legitimidade necessária para executar uma sentença quando esta é proferida pelos Tribunais Eclesiásticos.

A tendência utópica de toda a sociedade é sempre evoluir e permanecer alicerçada ao poder soberano do Estado, mas, este por outro lado tem o dever de respaldar as instituições que, manifestadamente, se mostram interessadas em aplicar a justiça com base nas normas positivistas e não somente na exegese do direito. Uma justiça que pode ser cega para não ver quem está sendo julgado deve ter os ouvidos apurados para saber diferenciar as verdades.

Durante grande parte da história do Brasil, a influência da Igreja Católica sempre esteve presente. Praticamente todas as normas legais foram inspiradas nas normas regidas pelos Tribunais Eclesiásticos e pelo Código de Direito Canônico, seja pelo método inquisitivo, seja até mesmo nas nulidades matrimoniais. Apenas em 1890, ao surgir da República é que nos vimos forçados a corroborar com a dissociação dos poderes, político e religioso.

A Igreja Católica até os dias atuais possui grande influência nas famílias brasileiras, inegável a confiabilidade na instituição, que pode ser até maior às leis que regem nosso ordenamento laico em determinadas comunidades. Denota-se que o presente estudo abordará os aspectos gerais inerentes ao direito matrimonial canônico e ao direito processual penal em específico no âmbito da prova emprestada e as hipóteses reais de colaboração processual por parte dos Tribunais Eclesiásticos.

Embora autônomos e independentes ambos os ritos processuais atuam juntos no mesmo propósito quando se refere a busca pela verdade real, pois, 
norteiam os mesmos indivíduos, e se ajustam no respeito às normas pautadas em uma lei maior, o respeito pelas normas em prol da convivência harmoniosa de uma sociedade.

O presente se encerra com as Considerações Finais, nas quais são apresentados pontos conclusivos destacados, seguidos da estimulação à continuidade dos estudos e das reflexões sobre o princípio da busca pela verdade real no processo canônico e processo penal.

\subsection{PARA O PRESENTE ARTIGO FORAM LEVANTADAS AS SEGUINTES HIPÓTESES:}

A soberania e autonomia processual das normas eclesiásticas perante 0 estado laico;

A busca pela verdade real no direito matrimonial canônico e no processo penal; $\checkmark$ A possibilidade de colaboração processual do processo canônico para a busca pela verdade real no processo penal.

Quanto à metodologia empregada foi utilizado o método dedutivo indutivo. Nas diversas fases da pesquisa, foram acionadas as técnicas, do referente, da categoria, do conceito operacional e da pesquisa bibliográfica.

\section{O LAICISMO DEMOCRÁTICO}

Para o homem, que é um ser social, e responsável por sua própria conduta e influência perante o mundo, seja ela positiva ou negativa. $O$ agir, emrelação aos seus pares é necessário apresentar normas que estejam ligadas diretamente ao seu cotidiano. Prepondera expor, que a Constituição da República Federativa do Brasil de 1988 em seu preâmbulo busca a proteção divina com o intuito de assegurar o exercício dos direitos sociais e individuais:

Nós, representantes do povo brasileiro, reunidos em Assembléia Nacional Constituinte para instituir um Estado Democrático, destinado a assegurar o exercício dos direitos sociais e individuais, a liberdade, a segurança, o bemestar, o desenvolvimento, a igualdade e a justiça como valores supremos de uma sociedade fraterna, pluralista e sem preconceitos, fundada na harmonia social e 
comprometida, na ordem interna e internacional, com a solução pacífica das controvérsias, promulgamos, sob a proteção de Deus, a seguinte CONSTITUIÇÃO DA REPÚBLICA FEDERATIVA DO BRASIL.

Em uma acurada definição de laicidade democrática, Dr. Gilberto Callado de Oliveira (2012) esclarece que partes do texto da Constituição carecem de força normativa. Sim, porque o preâmbulo funciona como legitimador da Constituição, como elemento indicador de interpretação e de criação da norma, segundo a maioria dos juristas e doutrinadores. Precisamente o princípio mais importante a ser levado em conta no processo de elaboração do direito é o princípio que rejeita o relativismo ateu e aviventa e renova a tradição cristã da esmagadora maioria dos brasileiros: a tradição em reverenciar os ministérios de nossa fé, tal como fez o índio ao apontar para o altar e, depois para o céu, na fiel descrição de Pero Vaz de Caminha da cerimônia da primeira missa em 1500, em terras de Vera Cruz. Em sua exposição acrescenta que, se a Constituição foi promulgada "sob a proteção de Deus", é sob tal linha principiológica que todas as normas devem ser elaboradas na esfera legislativa.

Diante de um Estado democrático de direito denominado laico, é pertinente esclarecer a desmesura do preâmbulo constitucional com o parágrafo único do art. $1^{\circ}$ da Constituição da República Federativa do Brasil de 1988, ao esclarecer que o poder emana do povo:

Art. 1ำ A República Federativa do Brasil, formada pela união indissolúvel dos Estados e Municípios e do Distrito Federal, constitui-se em Estado Democrático de Direito e tem como fundamentos:

I - a soberania;

II - a cidadania;

III - a dignidade da pessoa humana;

IV - os valores sociais do trabalho e da livre iniciativa; $\mathrm{V}$ - o pluralismo político.

Parágrafo único. Todo o poder emana do povo, que o exerce por meio de representantes eleitos ou diretamente, nos termos desta Constituição.

O Estado brasileiro é constitucionalmente laico, mas não é ateu. Sua laicidade é regrada, na medida em que são invioláveis os direitos de crença . 
Sem as leis amparadas na graça divina, sem a referência da presença de Deus em nossas vidas, tudo seria permitido, e os padrões morais e comportamentais, perderiam sua razão de existir, e, infelizmente estaríamos diante de absurdos inimagináveis na manipulação da vida.

\section{O PODER DE JURISDIÇÃO DA IGREJA}

$\mathrm{Na}$ sociedade o direito natural prevalecerá, podendo ser considerado como uma fonte do direito canônico. A Igreja Católica se interessa de forma muito especial por todos os direitos e deveres humanos fundamentais do homeme, a partir desses direitos, nasce o direito eclesial positivo.

O propósito do direito canônico é firmar a comunhão jurídico-eclesial para proteger os direitos de cada um de seus fiéis, seja dentro ou fora de sua instituição, como assim faz também o direito penal.

Na denominação "poder de jurisdição" está compreendido o conjunto de poderes existentes na Igreja que têm sentido estritamente jurídico, enquanto tem uma projeção externa e vinculante. A jurisdição compreende qualquer poder necessário para dirigir a comunidade ao seu fim.

$\mathrm{Na}$ história eclesiástica, o termo iurisdictio substitui progressivamente auctoritas, para referir-se ao exercício do poder, e não só a função ministerial de serviço. Preponderante se faz distinguir bem o uso do seu significado que, tanto na história quanto no uso ordinário, difere do uso do código vigente.

Em âmbito canônico, a palavra jurisdição compreende uma realidade muito mais ampla do que nem âmbito laico. Embora dito que o direito como atualmente conhecido tem sua origem no direito canônico, necessária retificação oportuna com relação à jurisdição, pois ambas as concepções provêm do direito romano. De fato, iurisdictio no direito romano primitivo era uma parte do mais amplo poder de imperium, isto é, um setor do supremo poder que inicialmente pertencia ao Rei. Em época posterior, aos Magistrados Superiores e, enfim, ao Imperador. Este imperium ou poder supremo incluía o poder de julgar, ius dicere, de pronunciar (dizer) o direito em caso de conflito. 
Posteriormente, a iurisdictio não foi mais compreendida como parte ou setor do poder de imperium, mas passou a significar o conjunto do poder jurídico e político sobre um determinado território.

No moderno direito laico conserva-se ainda a acepção primitiva romana, em sentido estrito, e por jurisdição se entende somente o poder de julgar, de resolver controvérsias, em definitivo, o poder pertencente aos órgãos judiciais.

Contrariamente, no direito canônico, foi conservada a acepção romana posterior, mais ampla e tardia que data do período Justiniano, e por jurisdição se entende o poder de governo da sociedade eclesial, e não somente o poder de julgar.

Oportunamente, estes esclarecimentos históricos e comparativos permitem afirmar a noção canônica de jurisdição, o poder público por meio do qual se regula a estrutura organizativa da Igreja, assim como a atividade dos fiéis em base ao seu específico fim comunitário, espiritual e apostólico. Trata-se, entretanto, do poder de vincular outros, em vista dos interesses gerais da Igreja, com projeção externa. Tal poder faz parte somente do munus regendi, enquanto tal munus, no confronto de certas realidades, exige um poder jurídico, vinculante externamente e limitado hierarquicamente, de acordo com o ofício. O novo Código de Direito Canônico mantém o uso genérico da noção de poder de jurisdição, mas o cân. 130 prefere se referir a poder de regime ou poder de governo. Somente em três ocasiões é usado o termo jurisdição no mesmo sentido da concepção laica, isto é, poder judicial (cân. 1417, cân. 1469 e cân. 1512).

Além disso, evita-se o uso impróprio porque o poder de jurisdição se distingue do poder de ordem (cân. 274), que em si não é potestas.

\section{OS DIREITOS DA IGREJA E DO PAPADO}

A sacralização da vida social corresponde à ordem eclesiástica, porque o sagrado pertence de iure absoluto à Igreja, e só à Igreja, que professa a verdadeira religião, tem o poder de, na ordem espiritual, orientar a relação salvífica dos homens com Deus. Quem, com sincero desejo de encontrar a 
verdade, olhar o curso da história e estudar as verdades sobrenaturais reveladas, verá que na Igreja Católica se cumpriram todas as profecias do Antigo Testamento; que durante a feroz perseguição por Ela sofrida durante os três primeiros séculos de sua existência, jamais foi vencida; que a Sua origem divina

está na admirável vida de Jesus Cristo com os seus milagres e sua impressionante doutrina; que ao aparente fracasso da cruz, seguiu-se o triunfo, a vitória da Ressurreição. E, assim, todas as dúvidas do incrédulo desvanecerão.

O direito da lgreja ensinar os povos e conduzi-los à eterna felicidade está

fundado no direito mesmo de Cristo, cuja régia dignidade exige, "que a sociedade inteira se ajuste aos mandamentos divinos e aos princípios cristãos, ora ao estabelecer leis, ora ao administrar a Justiça, ora finalmente ao formar as almas dos jovens na sã doutrina e na retidão dos costumes" . Governantes, políticos e juristas deveriam entender bem isso, e não se deixarem influenciar

por uma democracia liberal e igualitária, toda ela saturada dos erros da modernidade. Se eles negam o próprio Deus e Seus direitos, como irão respeitar (ou reconhecer) os direitos das pessoas? É sabido que a unidade entre a fé e a política do direito foi uma vivência histórica da Cristandade medieval, época em que a luz de Cristo, cuja lâmpada é a Igreja, se projetava sobre toda a sociedade temporal.

Como tantas vezes já enfatizamos nesta obra, a Revolução procura contrariar a Religião e o mundo sacralizado, e por isso induziu os legisladores a regular o laicismo para diminuir e, se possível, fazer desaparecer a jurisdição da Igreja, como se vê no chavão de Cavour, libera Chiesa nel libero Stato, de modo que a Igreja e o Estado são livres nos compartimentos de suas respectivas atividades, como se ambos se desconhecessem mutuamente.

Na história eclesiástica, alguma vez a hierarquia contribuiu para aprofundar essa divisão, sob a enganosa esperança de que o Estado republicano permitisse à Igreja maior liberdade de ação. A política de ralliement do pontificado leonino, aderente à Terceira República Francesa, não fez senão potencializar o processo de laicização e de descristianização da França. O principal argumento de aderência, utilizado por Leão XIII, na encíclica Au Mileu des Sollicitudes, foi o de 
diferenciar poderes constituídos e legislação: a legislação, sendo obra dos homens que estão no poder, depende muito mais deles, de sua qualidade moral, que da forma constituída de governo . Não tardariam muitos meses, após a morte do Papa, para o governo francês romper relações com a Santa Sede e aprovar a Loi concernant la Séparation des Eglises et de l'Etat, que suprimia qualquer reconhecimento público e financiamento da Igreja, considerava a religião apenas na sua dimensão privada e não em sua dimensão social, estabelecia o confisco dos bens eclesiásticos pelo Estado, enquanto os edifícios de culto eram concedidos gratuitamente a 'associações de culto' erigidas e dirigidas pelos fiéis, sem aprovação da Igreja. A Concordata de 1801, que havia regulado durante um século as relações entre a França e a Santa Sé e que Leão XIII havia querido preservar a todo custo, foi rasgada em mil pedaços" . Na verdade, o processo de secularização do Estado transforma o Reinado de Cristo em um reinomundano, cujo poder juspolítico está longe de obedecer ao Sumo Ordenador douniverso, Àquele que o rege de modo perfeitíssimo. A obediência secularizada tem outro pendor, outros desígnios; concentra-se em uma ordem multinacional diametralmente oposta à sede da Cristandade. Roma, ao final, sendo o centro da Teocracia universal, poderia, no futuro, transformar-se no centro da secularização universal, como pressagiava, antes do ralliement, o próprio Pontífice .

Se a Igreja volta os seus olhos permanentemente ao Céu, por que o Estado haveria de fixar o seu olhar para o inferno? O Estado laico sempre é tentado a isso. $\mathrm{E}$ não faltaram fatos históricos do triste espetáculo do laicismo revolucionário e anticristão. Na Segunda República Espanhola, a perseguição religiosa produziu-se numa escalada de terror. A Constituição de 1931 reduziu a Igreja a simples categoria de associação, dissolveu as ordens religiosas e proibiu o ensino religioso. Viria a ser promulgada depois, em 1933, a Ley Organica de Confesiones y Congregaciones Religiosas, que proibia qualquer manifestação de culto fora dos edifícios religiosos e impunha a remoção dos símbolos e imagens religiosas das escolas, edifícios públicos, praças e ruas. Nos poucos meses que antecederam o Alzamiento Nacional, já se iniciavam as perseguições 
cruentas. A emblemática simulação de fuzilamento da enorme estátua do Sagrado Coração de Jesus, situada no Cerro de los Angeles, simboliza tragicamente um autêntico massacre perpetrado contra os católicos e Sua Igreja. Milhares de fiéis, sacerdotes, religiosos e religiosas foram assassinados in odium fidei. Incendiaram-se incontáveis igrejas, conventos e edifícios católicos, precedidos de ultrajes sacrílegos ao Santíssimo Sacramento. No México, a Constituição de 1917 negou personalidade jurídica à Igreja, impedindo-a de possuir bens imóveis, proibindo o culto público fora dos templos e restringindo 0 ministério sacerdotal aos mexicanos de nascimento. A infame Ley Calles, de 1926, recrudesceu os ataques aos direitos da Igreja, com a dissolução dos mosteiros, a proibição do uso de hábitos religiosos fora dos templos, do ensino religioso nas escolas primárias e dos votos religiosos. Houve resistência dos católicos espanhóis e mexicanos às políticas legislativas de seus países, e sobrevieram as guerras, a guerra civil espanhola e a guerra cristã. Nelas havia uma finalidade juspolítica comum de sublevação em armas contra o poder constituído, inspirada no ideal de uma restauração católica.

A perda da sacralidade na vida política e social, que representa a separação entre a Igreja e o Estado, entre a ordem temporal e a ordem espiritual, afeta profundamente os direitos da Igreja e do Papado, os quais só seriam concedidos pela boa disposição legislativa do Estado. A Igreja é uma sociedade perfeita instituída pelo Divino Mestre, e para cumprir a sua missão delegada por Ele, na sua própria esfera de influência e ação, não pode submeter-se ao poder arbitrário do Estado nem ao poder de nenhuma outra instituição. O laicismo político jurídico frustra por isso os desígnios de Deus, de subordinar a cidade do mundo (Estado) à Sua cidade (Igreja), mediante a dialética transcendente da história . No presente histórico, muitos Estados não confessionais assumem uma posição de neutralidade perante a religião, o que não significa que sejam Estados ateus ou antirreligiosos. Mas isso não é suficiente. Para o bem das duas sociedades - a sociedade católica e a sociedade política -, o ordenamento jurídico deve respeitar a soberania de uma e de outra nas suas esferas de atribuição. 
A natureza e fins das duas sociedades indicam que o poder eclesiástico e o poder civil não são absolutamente independentes, como se ambos coexistissem em mundos ético-jurídicos distintos e isolados, mas em um sistema de mútua relação e união. Ambos os poderes provêm do mesmo poder régio de Deus e, no que tange aos deveres, cada qual deve colocar à disposição do outro a sua influência, e prestar também o apoio das suas ações, para o bem dos mesmos súditos, já que a educação moral e religiosa da Igreja favorece em tudo e por tudo a formação do bom cidadão, e em última instância a felicidade do povo.

O interesse da ciência das leis pelos direitos da Igreja e do Papado concentra-se na orientação do magistério eclesiástico no processo de criação das leis, em decorrência da plenitude de ação evangelizadora da Igreja na ordem temporal. Nos dias atuais, esta preponderância foi eclipsada pelo livre pensamento, o que não impede que a Igreja se oponha a certas proposições normativas - v. g. o divórcio, o aborto, a eutanásia, a união homossexual -, que atentam contra as verdades da fé e os princípios da ordem natural e cristã, tendo em vista que a vivência dessas normas tem ocasionado graves prejuízos à fé católica e, por via reflexa, à paz social e à moralidade pública. É direito da Igreja fazê-lo, de defender as nações dos perigos que certas políticas legislativas possam trazer para a sociedade civil. É direito precípuo do Sumo Pontífice fazêlo, em nome da Igreja, apesar dos erros propagados pelo liberalismo e pelo progressismo católico, que sustentam a adaptação da Igreja aos erros do mundo. Tais erros foram já compendiados por Pio IX, os quais se resumem na seguinte proposição por ele condenada: "O Romano Pontífice pode e deve se conciliar e recompor com o progresso, com o liberalismo e com a civilização moderna" . A instituição divina do papado não outorga ao Sumo Pontífice transigências com as supostas exigências da sociedade moderna, para contrariar verdades da fé. É seu direito - mais que um direito, um dever - defender as leis de Deus e a liberdade de ação da Igreja com zelo apostólico, denunciando os desvios morais de sua época.

Não poderá haver nenhuma norma constitucional de maior importância que possa intervir no exercício dos direitos da Igreja, a não ser para coibir 
eventuais erros ou abusos que, uma vez exteriorizados, ficam sujeitos à apreciação do Estado. Tenha-se bem presente que estes erros e abusos podem ocorrer, quando os membros da Igreja, notadamente os que se destacam na ordem hierárquica, atentem contra a ordem legal. Com muita tristeza vemos alguns prelados, em plena comunhão com a teologia da libertação, levarem a Igreja a atuar como instrumento de luta de classes, utilizando uma metodologia pastoral para transformar a Igreja numa organização integralmente marxista. Há uma clara cooperação entre eles e certos políticos de esquerda com o fim próprio de levar o Brasil a uma ditadura bolivariana. Nesta conjuntura tão perigosa, não há outro remédio senão o Estado intervir.

Pesa sobre o Estado a obrigação de reconhecer a existência de coisas que pertencem à Religião e disciplinar a consectária união das duas sociedades, semelhante à que existe entre a alma e o corpo, conforme à doutrina tradicional da Igreja. No processo preceptivo restaurativo, não haverá lugar para o laicismo nem para a heterodoxia, porque as diferentes religiões não têm os mesmos direitos que Jesus Cristo concedeu à Igreja por Ele fundada. Reconhecemos que hoje isso não seria realizável. No Brasil, são inúmeras as seitas dissidentes da Igreja Católica Apostólica Romana e muitas outras religiões de diversas origens, com suas legiões de seguidores, o que torna praticamente impossível a união mútua entre a Igreja e o Estado, ou este dar preferência àquela. $O$ regime de separação e de liberdade de culto é a situação constitucional que vigora. O direito de crença e de livre exercício de culto estão de certo modo protegidos, através de ameaça penal contra os que venham a conspurcar esses bens jurídicos. Além disso, o regime constitucional não é indiferente à religião, pois concede efeitos civis ao casamento religioso (art. 226, $\S \S 1^{\circ}$ e $\left.2^{\circ}, C F\right)$, admite a educação religiosa em escolas públicas de ensino fundamental (art. 210, $\S 1^{\circ}, \mathrm{CF}$ ), prevê a prestação de assistência religiosa a entidades civis e militares de internação coletiva (art. $5^{\circ}$, VII, CF). Tais garantias não deixam de ter a sua importância no contexto da neutralidade do Estado, já que este não se confunde com a nação, com o povo majoritariamente cristão. $\mathrm{O}$ 
Estado não pode ignorar a fé do povo, nem as festas e os feriados religiosos, as igrejas e as imagens sagradas em locais públicos.

Não pode, também, o Poder Judiciário, imiscuir-se em questões de competência canônica, isto é, em matérias que respeitam às normas internas da Igreja. Já no âmbito do direito internacional, o clero teria o direito de estar dependente da Santa Sé, numa situação jurídica que os diferenciaria dos demais nacionais, como foi outrora no Antigo Regime. Caberia ao Estado, portanto, respeitar essa dependência, e mais concretamente os tribunais próprios para julgarem os membros do clero.

A história tem revelado, porém, que o laicismo oficial se tornou inimigo obstinado da Igreja Católica e da Moral Cristã, do mesmo modo que a neutralidade em relação à verdade e ao erro, na realidade se tem colocado a favor de todos os erros contra a única verdade. A proclamada neutralidade do laicismo em relação à Religião e às suas leis morais não é senão uma militância ateia, ou, como declara Leão XII, "ele é o ateísmo menos o nome" . Pouco a pouco a ideia de separação entre a Igreja e o Estado se vai transformando em obsessiva política de banir, da vida pública, toda e qualquer manifestação religiosa, tal como o fez o Conselho da Magistratura do Rio Grande do Sul, ao decidiu retirar crucifixos e outros símbolos religiosos existentes nos espaços destinados ao público nos prédios do Poder Judiciário. A base argumentativa do acórdão não poderia ser mais enganosa: "A presença de crucifixos e demais símbolos religiosos nos espaços do Poder Judiciário destinados ao público não se coaduna com o princípio constitucional da impessoalidade na Administração Pública e com a laicidade do Estado brasileiro" .

Na perseguição implacável que na atualidade vem sofrendo a Igreja não há senão uma grave contradição, pois ela se tornou após o triunfo sobre a barbárie a guardiã do direito civilizado. O seu triunfo sobre as perseguições que sofreu ao longo de sua história é inconteste, e está alicerçado nas palavras do próprio Cristo Rei ao primeiro Papa: "Tu és Pedro, e sobre esta pedra edificarei a minha Igreja, e as portas do inferno não prevalecerão contra ela" . E assim 
continuará em sua obra redentora, o que nos faz confiar que, num futuro próximo, haverá profundo respeito das leis do Estado aos direitos da Igreja e do Papado.

\section{O PRINCÍPIO DA SEPARAÇÃO DOS PODERES}

O Brasil foi agraciado com grande influência da Igreja Católica em suas normativas. Algumas regulamentações, ou grande maioria delas, foram calcadas no Código de Direito Canônico, apenas em 1890, ao surgir a República houve a dissociação dos poderes, político e religioso. Na esfera constitucional, o Direito Canônico possui completa autonomia, soberania e independência processual perante o Estado na esfera matrimonial religiosa, mantendo-se regrada na legislação, administração jurídica, e impedimentos.

Não é possível delimitar qualquer exposição acerca do tema sem adentrar no assunto sem o que pensa a respeito da concepção do princípio da separação dos poderes, prescindindo da sua real aplicação prática, surgiu no século XVIII, e serve como um meio de evitar os abusos do poder e alcançar, através desta separação, o equilíbrio e o utópico estado de direito, isto é, favorecer a submissão do próprio poder à legalidade, excluindo um exercício arbitrário do poder.

A evolução histórica levou à separação dos poderes legislativo, executivo e judicial. Analisando o tema, e expondo suas afirmativas Pe. Valdinei de Jesus Ribeiro nos brinda que com o princípio de separação dos poderes, no caso da Igreja eles possuem uma aplicação secundária. Para o direito Canônico o matrimônio é um negócio jurídico de caráter contratual qual se distinguem três elementos fundamentais, a capacidade jurídica dos contraentes, assegurada por todos os requisitos prescritos por lei e, em particular, da ausência de impedimentos; a prestação de válido consentimento por parte de ambos os nubentes; e a observância da forma canônica, segunda as modalidades estabelecidas pela Igreja.

O poder de jurisdição ou de regime, na lgreja, tem um caráter pessoal e pleno, enquanto pertence de modo próprio, aos órgãos eclesiais capitais (Papa e Bispos nos respectivos âmbitos), mesmo se depois é exercido de modo vigário, 
ordinário e delegado. Isto significa que na Igreja não exista três poderes distintos entre si, nem três organizações separadas, porque as três funções de poder são exercidas em dependência da compreensão teológica da estrutura hierárquica e ministerial da Igreja. Tal poder, pessoal, pleno e único, é o que configura no atual ordenamento canônico, sem ratificar que seja esta a única tradução jurídica possível da realidade eclesiológica e ministerial da potestas.

A impostação pessoal do poder de jurisdição torna impensável um verdadeiro e próprio controle recíproco do exercício do poder.

Todavia, mesmo se não se conhece a tripartição do poder, o cân. 135, §1 estabelece uma distinção de funções: legislativa, executiva e judicial. Estas três funções têm entre si uma relação de moderação que permite afirmar na Igreja o princípio de legalidade e a exclusão de arbitrariedade. A moderação não é tão radical a ponto de poder ser considerada um verdadeiro controle dos poderes, enquanto todas as três funções têm como titular próprio um mesmo sujeito. A distinção decorrente do exercício vicário de cada função favorece, porém, o respeito do direito da parte dos fiéis e da própria comunidade. A afirmação da legalidade e a exclusão da arbitrariedade são funções específicas do poder judicial .

A função judicial, enquanto parte do poder de jurisdição, consiste no ius dicere, isto é, no declarar o direito nas situações controvérsias e a sua aplicação. O poder judicial deve ser exercido modo iure praescripto, vale dizer, no modo determinado pelo direito. A resolução judicial é precedida pela investigação dos fatos e das leis a serem aplicadas. Desta forma, destaca-se a dupla dimensão do poder judicial, a potestas cognoscendi relativa à instrução da causa e a potestas definiendi relativa à decisão, com objetivo de garantir o princípio de legalidade na comunidade eclesial. A exigência de fazer valer o princípio da legalidade se concretiza através da reivindicação dos próprios direitos em foro eclesiástico (cân. 221).

Tal reivindicação não deve ser interpretada exclusivamente como visando os fins individuais a que se destina, mas como modo de contribuir a eliminar através da ordem jurídica uma situação que, em consciência, se retém estranha 
ao patrimônio de valores, que todos têm o dever de defender de modo paralelamente responsável (cân. 208). A atividade judicial assume assim uma função comunal, fundada no controle da legitimidade e da aplicação da justiça às situações controversas; não são estranhos ao controle judicial os atos da própria autoridade (cân. 1400, §2 e cân. 1445, §2).

Gozam de modo ordinário deste poder os juízes e os colégios judicantes, que não pode ser delegado, enquanto os juízes não podem confiar as funções a alguém que não seja constituído publicamente como juiz. Expõe ainda que a exceção existe na possibilidade de exercício delegado do poder judicial quando o Papa ou o Bispo confiam a um tribunal uma causa por lei (no caso do Papa Cân. 1405, §1 e cân. 1442) ou por tê-la reservado (no caso do Papa - cân. 1417, e do Bispo - cân. 1419), é de sua competência. Os juízes, ao contrário, não podem delegar o seu poder, exceto para os atos preparatórios da decisão, entre eles a coleta das provas (cân 135, §3). Os leigos podem receber o ofício de juiz, seja para exercê-lo como membro de um colégio, juntamente a dois clérigos (cân. 1421, §2), seja, sobretudo, para exercê-lo como juiz instrutor (cân. 1428, §) .

\section{O QUE É UM TRIBUNAL ECLESIÁSTICO?}

Com relação aos meios organizacionais da Igreja Católica, o poder supremo é exercido pelo Romano Pontífice, chamado de Sé Primeira, ou o Supremo Tribunal, sendo este, o último grau de jurisdição, ou seja, de suas decisões não se permite recurso, (cân. 1.404). É o único Tribunal unipessoal, do mundo, ante sua magnitude conferida ao cargo. Imediatamente, em grau inferior, estão a Rota Romana e Rota Espanhola, que são egrégios tribunais colegiados, que tem por competência julgar, originariamente, as causas referentes aos Bispos, Superiores Maiores das Ordens Religiosas, Dioceses e outras pessoas eclesiásticas, e em grau de recurso, outras causas que lhe são destinadas pelo direito canônico.

O direito canônico respalda a qualquer fiel católico, recorrer diretamente à Sé Primeira. Em cada Diocese, o Bispo é tido como juiz de primeira instância, 
que pode também delegar esta função, geralmente a um Vigário Judicial, nomeando juízes eclesiásticos (cân. 1419). O Vigário Judicial, em união com o Bispo, forma com os demais Juízes o Tribunal Eclesiástico Regional de primeira instância, (cân. 1420).

O Vigário Judicial funciona como Presidente deste Tribunal Eclesiástico, que atua sempre colegialmente, em turnos de três juízes. Estes Juízes são, em via de regra, sacerdotes, porém o código de direito canônico faculta às Conferências Episcopais a nomeação de juízes leigos (cân. 1421).

Portanto, o libelo (como é chamada a petição inicial de pedido de declaração de nulidade matrimonial), deve ser requerido, primeiramente, junto ao Vigário da paróquia que processará o caso (cân. 1468).

\section{AUTORIDADE DO PODER ECLESIAL}

É possível dizer que existe, do ponto de vista jurídico, o poder eclesial que significa referir-se à existência de um poder jurídico na Igreja, que deve ser entendido no âmbito da posição jurídica ativa com natureza de potestas.

Em consequência, o poder eclesial, é o poder jurídico do qual são titulares alguns entre os fiéis e que consiste na capacidade de vincular outros fiéis, através das próprias instruções, em detrimento do bem comum. Os detentores deste poder são pessoas públicas, às quais são confiados, de modo variado (próprio, vigário, ordinário, delegado ou subdelegado), ofícios eclesiásticos, em virtude do qual exercem (obrigatoriamente) a autoridade.

A obrigatoriedade refere-se, antes de tudo, aos mesmos titulares do poder, pois não podem abandonar o seu exercício, nem ultrapassar os limites. A obrigatoriedade refere-se também aos fiéis destinatários das decisões da autoridade. Todas as decisões têm caráter de comando jurídico. São declarações de vontade que produzem nos destinatários uma sujeição jurídica.

Considerando a existência de confusão gerada por certas terminologias, inadequadas jurídica e teologicamente, para o Pe. Valdinei de Jesus Ribeiro convém esclarecer que este poder jurídico se distingue claramente de outras funções de autoridade, denominadas às vezes potestas: poder de magistério ou 
de ensinar; poder de ordem ou de culto. A confusão se estabelece em base à conexão material, que se refere a matérias que muitas vezes exigem a conferência pública de uma função eclesial, e a conexão pessoal que coincidem com frequência nas mesmas pessoas que exercem poderes jurídicos. É possível chamar estas funções pelo termo sacra potestas, que em diversos graus é recebida com a recepção do ministério ordenado.

Todavia, estas realidades só impropriamente podem ser consideradas poder jurídico que cria submissão/sujeição, mesmo sendo funções da autoridade vinculada aos tria munera cristológicos. Os tria munera pertencem com radical igualdade a todos os batizados, e isto é o fundamento da comunhão e da responsabilidade subjetiva eclesial. Mas os munera são desenvolvidos com diversos estatutos jurídicos, dependentes da ordenação, sendo esta diferença ontológica, entre batizados e ordenados, a base da estrutura ministerial da Igreja, constituída para a utilidade da comunidade.

Aos ministros cabe a missão de confrontar a comunidade com 0 Evangelho, não sendo o ministério uma delegação da comunidade, mas uma vocação de origem divina. Pois bem, a referida diferença ontológica em relação aos tria munera não se traduz no binômio poder-sujeição, seja pela matéria objeto de cada munus, seja pela insuficiência da ordenação em si mesma, seja, enfim, pela incidência efetiva da correspondência e da imprescindível utilidade comunitária do poder. Só o munus regendi pode dar lugar (após prévia provisão de certos ofícios eclesiásticos ou mandato) a um verdadeiro poder, no sentido jurídico do termo; seria melhor fazer referência às outras funções com os termos ministérios ou serviços, e não potestas. Ainda, o munus regendi é recebido por todos os batizados; para melhor servir à utilidade comum, todos os batizados, também os não-ordenados in sacris, têm uma radical condição de exercer o munus regendi na forma jurídica de potestas, podendo ocupar alguns ofícios eclesiásticos para os quais têm as condições exigidas; são ofícios cuja competência gera vínculo sobre outros. 
Em suma, nem todos os ordenados são titulares do verdadeiro e próprio poder de regime, ou ao menos não em razão somente da ordenação, mas há a necessidade de um ato jurídico chamado missio canonica .

\section{O JUIZ NO DIREITO PROCESSUAL CANÔNICO}

A palavra juiz deriva do latim iudex, que à sua vez, integra dois conceitos sendo eles ius e dicere sendo aquele que pronuncia o direito. Para o Vigário Judicial Tarcísio Pedro Vieira tal pronunciamento é precedido por um conhecimento da causa, necessário para poder realizar a sua missão de iudicium dare. O juiz no direito canônico, é aquele que de modo individual ou colegial, foi legitimamente designado para exercitar o poder judicial, na dupla função de conhecer e decidir a causa, no modo estabelecido pelo direito; pessoa pública, cujas decisões gozam de autoridade e poder vinculador.

O poder próprio de julgar atribuído ao juiz, enquanto parte do poder de regime, pertence aos órgãos capitais. A sua organização é paralela aos ofícios daqueles que presidem as Igrejas Particulares, os seus agrupamentos e a Igreja Universal.

Em âmbito diverso das estruturas pertencentes à constituição hierárquica da Igreja Católica, o poder próprio de julgar se estrutura também em relação ao poder eclesiástico de governo reconhecido aos superiores dos institutos de vida religiosa clerical de direito pontifício (cân. 596, §2). O juiz próprio, neste caso, é determinado pelo próprio direito ou, subsidiariamente, pelo direito universal (cân. 1427).

No Livro II do Código de Direito Canônico ocupa-se da nomeação, qualidade e estabilidade dos ofícios capitais, no que se refere às figuras equiparadas ao Bispo Diocesano convém advertir que nem sempre têm os mesmos poderes em relação à matéria judicial, especialmente ao que se refere à nomeação e remoção dos juízes (cân. 1420, §5). Única exceção à designação automática do juiz próprio refere-se aos moderadores dos tribunais interdiocesanos, que pode acontecer através de eleições e ad tempus, de acordo com o documento de ereção (cân. 1423, §1; cân 1439, §3). 
Não convém que o Juiz Próprio exerça pessoalmente o poder judicial, considerando o conjunto de suas funções e as implicações de diversas ordens. Assim, cabe ao Juiz Próprio designar outros para exercer em seu nome o poder judicial.

\section{A SOBERANIA DA IGREJA EM RELAÇÃO AO ESTADO}

Oportuno destacar que para aplicação prática, algumas características da Justiça Eclesial ressalta alguns pontos que se diferenciam de outros ornamentos jurídicos, seja por causa de seu âmbito e objetivo, de ordem teológico-jurídica, seja devido aos seus próprios limites frente aos preceitos legais impostos.

O juízo eclesiástico é a discussão e definição diante de um tribunal eclesiástico de um litígio relativo à matéria em que a Igreja tem o poder de julgar. O cânone 1400 §1 do Código de Direito Canônico de 1983 descreve os objetos do juízo eclesiástico:

Cân. 1400 § 1. São objeto de juízo:

$1^{\circ}$ - direitos de pessoas físicas ou Jurídicas a serem defendidos ou reivindicados e fatos jurídicos a serem declarados;

$2^{\circ}$ - delitos, no que se refere à imposição ou declaração da Pena.

$\S 2$. Todavia, controvérsias originadas de atos do poder administrativo podem ser apresentadas somente ao Superior ou ao tribunal administrativo.

Mas, em conformidade com o cânone 1401:

Cân. 1401 Pelo seu poder próprio e exclusivo, a Igreja conhece:

$1^{\circ}$ - das causas relativas às coisas espirituais e das causas com elas conexas;

$2^{\circ}$ - da violação das leis eclesiásticas e dos atos caraterizados como pecado, no que se refere à determinação da culpa e à imposição de penas eclesiásticas.

Por direito próprio entende-se que a autonomia e independência da Igreja Católica no que tange debater determinadas questões, não precisa se reportar ao reconhecimento de jurisdição da parte de nenhum outro poder, por direito exclusivo próprio, entende-se que a Igreja Católica pode, sobre determinadas matérias não reconhecer a jurisdição de nenhum outro poder, sendo que eventuais decisões de outras autoridades não teriam efeito algum no interno ordenamento eclesial, a não ser por concessão expressa da própria lgreja Católica. 
A Constituição da República Federativa do Brasil de 1988, no capítulo que trata dos direitos e deveres individuais e coletivos elencado no art. 5o, incisos XVII a $\mathrm{XXI}$, determina regras gerais para a criação de o funcionamento de associações de pessoas. Fica estabelecido que, para fins lícitos, é ampla a liberdade de associação e que o Estado não pode interferir no seu funcionamento.

Art. 5 Todos são iguais perante a lei, sem distinção de qualquer natureza, garantindo-se aos brasileiros e aos estrangeiros residentes no País a inviolabilidade do direito à vida, à liberdade, à igualdade, à segurança e à propriedade, nos termos seguintes:

$(\ldots)$

XVII - é plena a liberdade de associação para fins lícitos, vedada a de caráter paramilitar;

XIX - as associações só poderão ser compulsoriamente dissolvidas ou ter suas atividades suspensas por decisão judicial, exigindo-se, no primeiro caso, o trânsito em julgado;

$X X$ - ninguém poderá ser compelido a associar-se ou a permanecer associado; $\mathrm{XXI}$ - as entidades associativas, quando expressamente autorizadas, têm legitimidade para representar seus filiados judicial ou extrajudicialmente;

É considerada associação a união de pessoas que se organizam para fins não econômicos, incluindo-se nesta categoria todas as pessoas jurídicas que exerçam atividades assistenciais, religiosas, culturais dentre outras, neste caso em particular, as igrejas e as organizações não governamentais.

Art. 44. São pessoas jurídicas de direito privado:

I - as associações;

II - as sociedades;

III - as fundações.

$\S 2^{\circ}$ - As disposições concernentes às associações aplicam-se, subsidiariamente, às sociedades que são objeto do Livro II da Parte Especial deste Código.

Art. 53. Constituem-se as associações pela união de pessoas que se organizem para fins não econômicos.

Parágrafo único. Não há, entre os associados, direitos e obrigações recíprocos. 
Embora não exista diferença empírica ou técnica entre sociedade civil sem fins lucrativos e associação, teoricamente podemos dizer a dicotomia que atorna única é com relação ao número de pessoas e os interesses que as envolvem. Certo é que, na maioria dos casos, a sociedade civil sem finslucrativos é instituída por um pequeno número de pessoas com a finalidade de atender à coletividade ou a um grupo determinado da coletividade que não os próprios sócios, enquanto a associação, normalmente, é composta por um grande número de pessoas, as quais visam, em sua grande maioria, ao interessedaqueles que a compõe. A princípio, pode-se compreender as três entidades como se segue:

- sociedade civil sem fins lucrativos, pode ser considerada a pessoa jurídica de direito privado que se forma através de uma reunião de mais uma pessoa e que visa beneficiar outras pessoas;

- associação é o agrupamento de pessoas, geralmente em maior número, que, embora possam também visar ao benefício de terceiros, sempre têm como objetivo o atendimento dos próprios associados ou de interesses destes.

- fundação é considerada como sendo o patrimônio que alguém separa do que the pertence para beneficiar, sempre, as outras pessoas que não 0 instituidor ou os seus administradores da entidade.

A Igreja Católica responde pelos atos de seus diretores e prepostos nos limites dos poderes a eles conferidos pelo estatuto neste caso, o Código de Direito Canônico. É o estatuto que estabelece até que o diretor pode praticar determinados atos sem autorização da assembleia geral, pois detém poderes para tanto .

O juízo ou julgamento de um assunto em questão de competência da Igreja pode ser objeto de julgamento: um fato a ser declarado, direito de pessoas físicas ou jurídicas a serem defendidos, exame de um delito para definir se é o caso de declarar ou impor uma pena, uma causa de beatificação de um servo de Deus ou de canonização de um beato. 


\section{A BUSCA PELA VERDADE REAL NO PROCESSO PENAL E NO DIREITO MATRIMONIAL CANÔNICO}

O Prudente Magistrado é o receptor imediato das provas produzidas tanto no processo penal quanto no processo de nulidades matrimoniais, e, com fundamento legal firma o seu livre convencimento para sentenciar a causa, conforme exposição do artigo 155 do Código de Processo Penal, pela redação dada pela Lei oㅜ 11.690, de 2008:

Art. 155 - O juiz formará a sua convicção pela livre apreciação da prova produzida em contraditório judicial, não podendo fundamentar sua decisão exclusivamente nos elementos informativos colhidos na investigação, ressalvadas as provas cautelares, não repetíveis e antecipadas.

Instituído de poder para proporcionar a prestação jurisdicional mais acertada, o Código de Processo Penal, vislumbra o princípio da busca da verdade real, conferindo ao juiz da causa poderes instrutórios para tanto. Não existem dúvidas de que a verdade real, é traduzida como verdade pura, um objetivo hipoteticamente inalcançável, quase sento tratado como uma utopia processual, da mesma forma que o processo civil, conforme o artigo 130 do Código de Processo Civil:

Art. 130 - Caberá ao juiz, de ofício, ou a requerimento da parte, determinar as provas necessárias à instrução do processo, indeferindo as diligências inúteis ou meramente protelatórias.

O direito canônico não diverge desta lógica de raciocínio, pois o Vigário Judicial ao sentenciar, deve formar seu convencimento de forma livre, valorando as provas tolhidas, cuja sentença deverá conter todos os motivos que auxiliaram a formar seu convencimento, conforme os cânones 1608 e 1611:

Cân. 1608 - 1. Para pronunciar qualquer sentença, requer-se no ânimo do juiz a certeza moral acerca do assunto que deve dirimir.

$\S 2$. O juiz deve fundar esta certeza no que foi alegado e provado. 
§ 3. O juiz deve avaliar as provas em conformidade com a sua consciência, respeitando as prescrições da lei acerca da eficácia de algumas provas.

$\S 4$. Se não tiver podido alcançar esta certeza, pronuncie não constar do direito do autor e absolva o demandado, a não ser que se trate de causa que goze do favor do direito, pois neste caso deve pronunciar-se em favor desta.

Cân. 1611 - A sentença deve:

I. dirimir a controvérsia discutida perante o tribunal, dando resposta adequada a cada uma das dúvidas;

$2{ }^{\circ}$ determinar quais as obrigações das partes decorrentes do juízo e como devem ser cumpridas;

$3 .^{\circ}$ expor as razões ou os motivos, tanto de direito como de facto, em que se baseia a parte dispositiva da sentença;

4. ${ }^{\circ}$ determinar o referente às custas da lide

O Código de Processo Penal, por sua vez, em caso de dúvidas, autoriza ao Magistrado buscar a prova, nos termos do art. 156 in verbis:

Art. 156 - A prova da alegação incumbirá a quem a fizer, sendo, porém, facultado ao juiz de ofício:

I- ordenar, mesmo antes de iniciada a ação penal, a produção antecipada de provas consideradas urgentes e relevantes, observando a necessidade, adequação e proporcionalidade da medida;

II - determinar, no curso da instrução, ou antes de proferir sentença, a realização de diligências para dirimir dúvida sobre ponto relevante.

O dispositivo legal autoriza a possibilidade do Magistrado, de ofício, determinar a produção de uma prova para firmar seu livre convencimento, no Código de Processo Penal existem outros dispositivos legais que tratam da produção de provas para o livre convencimento motivado na busca pela verdade real, entre eles os artigos 147, 209 e 234 respectivamente:

Art. 147 - O juiz poderá, de ofício, proceder à verificação da falsidade; 
Art. 209 - O juiz, quando julgar necessário, poderá ouvir outras testemunhas, além das indicadas pelas partes;

Art. 234 - Se o juiz tiver notícia da existência de documento relativo a ponto relevante da acusação ou da defesa, providenciará, independentemente de requerimento de qualquer das partes, para sua juntada aos autos, se possível;

Os entendimentos se conflitam, o legislador ao regulamentar a lei processual conferiu ao Prudente Magistrado a autonomia para determinar a produção de provas com um propósito de manter a segurança jurídica na solução de conflitos. Mas, no que se refere à fusão da busca pela verdade real entre duas instituições autônomas, paira a dúvida na possibilidade de uma colaboração ou complementação de informações, já que a soberania de uma em relação a outra se mostra plenamente indiscutível.

\section{A COLABORAÇÃO ENTRE PROCESSO CANÔNICO E PROCESSO PENAL}

Em 13 de novembro de 2008, na Cidade do Vaticano, o então Presidente da República Federativa do Brasil no uso da atribuição que lhe confere o art. 84, inciso IV, da Constituição, promulgou por meio do Decreto 7.107/2010, o acordo firmado entre o Governo da República Federativa do Brasil e a Santa Sé, relativo ao Estatuto Jurídico da Igreja Católica no Brasil.

Neste texto, houve a exposição de motivos considerando principalmente que a Santa Sé é a suprema autoridade da Igreja Católica, regida pelo Direito Canônico, o reconhecimento das relações históricas entre a Igreja Católica e o Brasil havendo também a reafirmada adesão ao princípio, internacionalmente reconhecido, da liberdade religiosa acompanhada de respaldo constitucional garantindo o livre exercício dos cultos religiosos, além de consolidar os tradicionais vínculos de amizade e colaboração existente entre os dois países. O Decreto regula diferentes assuntos, entre os quais, o estatuto jurídico da Igreja Católica no Brasil, o reconhecimento dos títulos de estudo, o ensino religioso nas escolas públicas, o matrimônio canônico e o regime fiscal. Contudo, é 
preponderante tecer breves comentários acerca dos artigos 12 e 13, dentre as possibilidades que foram conferidas em virtude da promulgação do Decreto 7.107/10:

Art. 12 - O casamento celebrado em conformidade com as leis canônicas, que atender também às exigências estabelecidas pelo direito brasileiro para contrair o casamento, produz os efeitos civis, desde que registrado no registro próprio, produzindo efeitos a partir da data de sua celebração.

$\S 1^{\circ}$. A homologação das sentenças eclesiásticas em matéria matrimonial, confirmadas pelo órgão de controle superior da Santa Sé, será efetuada nos termos da legislação brasileira sobre homologação de sentenças estrangeiras.

O presente artigo expõe o sacramento do matrimônio que pode ser reconhecido pelo direito civil, da mesma forma que a possibilidade de homologar sentenças proferidas por Tribunais Eclesiásticos, que declaram nulo um matrimônio.

Toda sentença proferida por um Tribunal Eclesiástico Católico passa pelo primeiro juízo de admissibilidade, também chamado de primeira instância, todo matrimônio é elevado a sacramento, de modo que a Igreja Católica guarnece seu vínculo, havendo decretação de nulidade matrimonial, haverá remessa dos autos ex officio ao juízo de segunda instância (cân. 1682, §1 e §2). Essa sentença é valida para a Santa Sé, e ratificada por ela, o governo brasileiro poderá homologar a sentença através do Superior Tribunal de Justiça, conforme pioneira decisão homologada pelo Superior Tribunal de Justiça através do preclaro ministro Felix Fischer cujo número do processo não é divulgado por se tratar de segredo de justiça, e, suas informações além das oficiais são meras especulações imprecisas.

Mas, o que prepondera é o entendimento de que não haverá novo julgamento do caso debatido, apenas, o acolhimento de uma sentença da mesma forma como acontece com outras sentenças estrangeiras. A decisão vem do Tribunal Eclesiástico, é confirmada pela Santa Sé, cabendo apenas ao governo brasileiro homologá-la. 
O cerne deste estudo é garantir que haja reconhecimento da soberania jurisdicional do processo canônico frente ao processo penal, mas, com a ressalva de que é possível a colaboração na busca pela verdade real. $\mathrm{O}$ artigo 13 do Decreto 7.107/10 garante o sigilo profissional do sacerdote, seja em atribuição de Vigário Judicial, seja em segredo sacerdotal:

Art. 13 - É garantido o segredo do ofício sacerdotal, especialmente o da confissão sacramental.

O presente artigo respalda o foro íntimo e o sigilo profissional, que todo ministro religioso tem dever e direito de guardar. Então não se pode, em hipóteses ou circunstância alguma, requerer o depoimento de um padre sobre qualquer coisa que ele tenha ouvido em confessionário ou até mesmo em um processo canônico. O que ele ouviu em confissão, tem o direito de guardar segredo, ninguém pode exigir que ele fale, igualmente sábio, o artigo 207 do Código de Processo Penal, apresenta o rol de pessoas proibidas de prestar depoimento ou testemunho em função de sua profissão, ministério ou ofício:

Art. 207 - São proibidas de depor as pessoas que, em razão de função, ministério, ofício ou profissão, devam guardar segredo, salvo se, desobrigadas pela parte interessada, quiserem dar o seu testemunho.

Desta forma, antevendo hipoteticamente que haja no âmbito processual penal, a apuração por parte do Ministério Público de um fato criminoso, no caso específico o crime de abuso sexual, por parte de um pai ou mãe, que estejam também demandando em processo canônico visando a nulidade de seu matrimônio, e, durante suas declarações perante o juízo eclesial haja apenas a ratificação dos termos já expostos junto ao Ministério Público Estadual é possível afirmar que não há fator impeditivo para que as declarações da parte, tolhidas no processo canônico poderão complementar a instrução criminal no processo penal, já que existe apuração de um fato ilícito.

O regramento do direito canônico e a própria instituição, alicerçam os regimentos que amparam, facultam e autorizam a colaboração processual, podendo haver ou não. Destarte, é merecedor expor que da mesma forma que 
o Estado laico, a Igreja também prevê punição para alguns denominados crimes eclesiais.

Diante desta penumbra jurídica, no dia 03 de maio de 2011, houve a publicação pela Congregação para a doutrina da fé, uma Carta Circular para auxiliar as conferências episcopais na preparação de linhas diretrizes no tratamento dos casos de abuso sexual contra menores por parte de clérigos. A chamada Carta Encíclica que também significa Carta Circular é um documento pontifício destinado aos Bispos de todo o mundo e, através destes para todos os fiéis. Todas as Cartas Circulares são usadas pelo Santo Padre com o intuito de exercer o seu Pontificado, podendo abordar um tema específico doutrinal ou moral, incentivar uma devoção, reprimir condutas, dentre outros.

A carta expõe dentre as importantes responsabilidades dos Bispos, a proteção dos menores, a formação dos futuros sacerdotes e religiosos, o acompanhamento dos sacerdotes, e a cooperação com as autoridades civis.

Esta última, trabalhada com o intuito de proporcionar maior conforto na colaboração processual entre as instituições. Visando assegurar o bem comum dos fiéis e, especialmente das crianças e dos jovens, o dever de dar uma resposta adequada aos eventuais casos de abuso sexual contra crianças e adolescentes, seja por clérigos, seja por leigos.

No tópico I. Aspectos Gerais, o item e) deixa bem claro a cooperação com as autoridades civis :

O abuso sexual de menores não é só um delito canônico, mas também um crime perseguido pela autoridade civil. Se bem que as relações com as autoridades civis sejam diferentes nos diversos países, é contudo importante cooperar com elas no âmbito das respectivas competências. Em particular se seguirão sempre as prescrições das leis civis no que toca o remeter os crimes às autoridades competentes, sem prejudicar o foro interno sacramental. É evidente que esta colaboração não se refere só aos casos de abuso cometidos por clérigos, mas diz respeito também aos casos de abuso que implicam o pessoal religioso ou leigo que trabalha nas estruturas eclesiásticas. 
O fato que chama atenção é a particularidade do texto quanto a colaboração em específico aos crimes de abuso sexual, que pode ser reportado às autoridades competentes do Estado, contudo, sem que haja prejuízo o foro íntimo do sacerdote, conforme previsão do art. 13 do Decreto 7.107/10.

O item taxativamente expõe que a colaboração não se limita apenas aos casos de abuso cometidos por clérigos, mas também a casos que comprometam fiéis ou leigos que trabalham nas estruturas eclesiásticas, desta forma, é possível uma interpretação analógica extensiva aos fiéis que não apenas trabalham, mas que se reportam às leis canônicas regidas pelos Tribunais Diocesanos e Interdiocesanos. Finalmente, é possível afirmar que acaso haja indícios de configurado crime que esteja sendo apurado pelo Ministério Público, e, a prova de sua materialidade e autoria se estenderem ao processo canônico, é possível uma colaboração processual, contudo, dentro das limitações e prerrogativas impostas pela lei.

\section{CONCLUSÕES}

Não é possível furtar-se ao entendimento de que o direito processual penal como é conhecido, possui sua herança e valoroso legado oriundo do direito canônico. Lamenta-se profundamente que o código de direito canônico não seja mais objeto de estudo em nossas grades curriculares das faculdades de direito, nem mesmo como contexto histórico. Adotando um direito de diagnoses, e, não de diagnósticos é possível ouvir o clamor da justiça com base nas autênticas raízes do direito, cuja humanização e dulcificação são derivadas do pensamento cristão. Um dos grandes desafios da Igreja Católica hoje é impor-se e expor sua soberania no que tange suas regras, leis e costumes. Deste modo, a lgreja expõe abertamente que é seu dever, através do direito eclesial, ser fonte de vida, justiça e liberdade, de modo que não é possível ignorar que as relações entre Igreja e Estado tenham uma repercussão direta em um país que possui a maior quantidade de católicos do mundo.

Não é eficaz abordar os fundamentos legais e processos inquisitoriais sem considerar a Igreja Católica como um modelo estrutural para o regramento 
de um rito processual. É de grande interesse por parte da sociedade que clama sempre por uma justiça social operante e, acima de tudo, justa ver que uma justiça puramente interessada na verdade pode funcionar. A Igreja Católica é uma das instituições mais antigas do mundo, e, pode-se dizer que é uma instituição confessional que tem acesso às relações diplomáticas, seja na esfera extrajudicial seja nas esferas civil e penal. $O$ presente artigo teve como finalidade, expor a autonomia do Processo Canônico e do Estado Laico frente aos procedimentos adotados por ambos. Conforme outrora afirmado, existe um abismo que se vê ligado por uma pequena e frágil ponte de colaboração processual entre ambos, que podemos denominar princípio da busca pela verdade real. 


\section{REFERÊNCIAS}

ABREU, Pedro Manoel. Processo e democracia: o processo jurisdicional como um locus da democracia participativa e da cidadania inclusiva no Estado democrático de direito. São Paulo. Conceito Editorial, 2011.

ATALIBA, Geraldo. República e Constituição, 2 ed., São Paulo: Melheiros Editores, 1998.

BRASIL. Decreto n. 7.107, de 11 de fevereiro de 2010 - Decreto nํ 7.107/10. Diário Oficial da República Federativa do Brasil, Brasília, DF, 11 fev. 2010.

Disponível

em:<http://www.planalto.gov.br/ccivil_03/_Ato2007010/2010/Decreto/D7107.htm> Acesso em: 05 fev. 2014.

BRASIL. Decreto-Lei n. 2.848, de 7 de dezembro de 1940 - Código Penal. Diário Oficial da República Federativa do Brasil, Brasília, DF, 7 dez. 1940.

Disponível em: <http://www.planalto.gov.br/ccivil_03/decreto-lei/del2848.htm> Acesso em: 06 fev. 2014

BRASIL. Decreto-Lei n. 3.689, de 3 de outubro de 1941 - Código de Processo Penal. Diário Oficial da República Federativa do Brasil, Brasília, DF, 3 out. 1941. Disponível em: <http://www.planalto.gov.br/ccivil_03/decretolei/del3689compilado.htm> Acesso em: 09 fev. 2014.

BRASIL. Lei n. 8.069, de 13 de julho de 1990 - Estatuto da Criança e do Adolescente. Diário Oficial da República Federativa do Brasil, Brasília, DF, 13 julh. 1990. Disponível em: <http://www.planalto.gov.br/ccivil_03/leis/l8069.htm> Acesso em: 09 fev. 2014.

BRASIL. Constituição da República Federativa do Brasil 1988. Diário Oficial da República Federativa do Brasil, Brasília, DF, 05 out. 1988. Disponível em: <http://www.planalto.gov.br/ccivil_03/constituicao/constituicao.htm> Acesso em: 09 fev. 2014

CAPPARELLI, Júlio César. Manual sobre o matrimônio no direito canônico. São Paulo: Paulinas, 1999;

CIFUENTES, Rafael Liano. Novo direito matrimonial canônico. Rio de Janeiro: Marques Saraiva, 1988;

CIFUENTES, Rafael Llano. Relações entre a Igreja e o Estado, 2 ed., São Paulo: José Olympio, 1989. 
COELHO, Vicente de Faria. Nulidade e anulação do casamento. Rio de Janeiro: Freitas Bastos, 1952;

DIAS, Maria Berenice. Manual de direito das famílias. Revista dos Tribunais, 4 ed. 2007;

GOEDERT, Pe. Valter Maurício. Sacramentos. Maravilhas da salvação. 2 ed., São Paulo: Paulinas, 2004.

GOÉS, Guilherme Sandoval. Neoconstitucionalismo e dogmática pós-positivista. In: BARROSO, Luís Roberto. (Org.) A reconstrução democrática do direito público no Brasil. Rio de Janeiro: Renovar, 2007.

GONÇALVES, Pe. Mário Luiz Menezes. Introdução ao direito canônico. 2 ed., Petrópolis: Vozes, 2004.

GRAU, Eros. Ensaio e discurso sobre a interpretação/aplicação do direito. 5 ed. São Paulo: Malheiros, 2009.

HOTAL, Jesús. O que Deus uniu. São Paulo: Loyola, 2006;

IONNES. Paulus Papa II. Sacrae disciplinae leges. 25 lanuarii 1983, Romae, Apud Sanctum Petrum, 26 in: AAS, 75 (1983), p. VII-XIV.

JESUS HORTAL, S.J. Casamentos que nunca deveriam ter existido. Uma solução pastoral, 12 ed., São Paulo: Loyola, 2004.

MEDRONI, Marcelo Batlouni. Linhas gerais do processo canônico. São Paulo. Ed. Revista dos Tribunais, Revista de Pro cesso, Ano 31 no 135, maio/2006, p.71/74.

MELO, Osvaldo Ferreira de. Fundamentos de política jurídica. Porto Alegre: Sergio Antonio Fabris, 1994.

OLIVEIRA, Gilberto Calado de. Projeto de Código Penal "Código de Morte" prestes a desabar sobre a cabeça dos brasileiros, 1 ed., São Paulo: Instituto Plínio Corrêa de Oliveira, 2012.

NOGUEIRA. Luiz Rogério. Gestão administrativa e financeira eclesiástica.

Petrópolis: Vozes, 2008.

PASOLD, Cesar Luiz (Coord.). Primeiros ensaios de teoria do estado e da Constituição. Curitiba: Juruá, 2010.

ROMA. Pontifício Conselho para os Textos Legislativos. Dignitas Connubii. Roma, Vaticano, 25 jan. 2005. Disponível em: 
$<$

http://www.vatican.va/roman_curia/pontifical_councils/intrptxt/documents/rc_pc intrptxt_doc_20050125_dignitas-connubii_po.html> Acesso em: 22 maio. 2021. ROMA. Carta circular para ajudar as conferências episcopais na preparação de linhas diretrizes no tratamento dos casos de abuso sexual contra menores por parte de clérigos. Carta Encíclica. Roma, Vaticano, 03 mai. 2011. Disponível em:

<http://www.vatican.va/roman_curia/congregations/cfaith/documents/rc_con_cf aith_doc_20110503_abuso-minori_po.html> Acesso em: 14 junho. 2021.

SACRAE DISCIPLINAE LEGES. Código de Direito Canônico. Quinto ano do pontificado de João Paulo II - Roma, Vaticano, 25 jan. 1983. Disponível em: < http://www.presbiteros.com.br/site/codigo-de-direito-canonico-em-portugues1983/> Acesso em: 25 junho. 2021. 